\title{
ASYMMETRY OF THE MANTLE STRUCTURE BENEATH THE MID-ATLANTIC RDGE
}

\author{
Jean Goslin and Daniel Aslanian \\ Unité de Recherche Associée "Domaines Océaniques", Brest, France
}

\begin{abstract}
Altimetry data from repetitive orbits of the GEOSAT satellite are interpreted together with sea-floor depths over the Mid-Atlantic Ridge, South of Iceland and South of the Azores. Geoid / Topography ratios indicate a strong asymmetry of the upper mantle structure in oceanic areas created since $35 \mathrm{My}$, extending several hundreds kilometers from Iceland to the Azores. A model including interaction between the MAR and two layers of mantle convection seems adequate to produce the observed asymmetry.
\end{abstract}

\section{Introduction}

Most models of upper mantle structure under oceanic ridges, either based on field observations, such as those exhaustively reviewed by Nicolas [1989] from ophiolites complexes, or those proposed from the study of mid-oceanic ridges [e.g. Phipps Morgan et al., 1987] consider a 2D-symmetry of mantle physical parameters about the ridge axis. This indispensable simplification, making models numerically resolvable, is adequate to explain most field surface observations. However, it appears to differ somewhat from the more complicated picture of the mantle which emerges from deep seismic tomography of oceanic domains [Honda and Tanimoto, 1987; Sheehan and Solomon, 1991; Montagner and Tanimoto, 1991] or from geochemistry [Dupré and Allègre, 1980; Schilling et al., 1983].

Moreover, several indications that oceanic accretion processes are indeed asymmetric have been published, even if they pertain to small-scale processes occurring in the ridges' axial domains themselves, as, for example, the location of focal mechanisms under the Mid-Atlantic Ridge near $23^{\circ} \mathrm{N}$ [Toomey et al., 1988] or the asymmetry in the free-air anomaly across the South Atlantic Ridge [Forsyth, 1990]. Finally, frequent episodes of asymmetric spreading have been observed along various ridge segments [e.g. Patriat, 1987]. However, the possibility that asymmetry in the accretion processes could affect mantle depths or be found on a larger scale has been scarcely investigated. Cochran [1986] shows evidence of such an asymmetry in the depth vs. age curves on intermediate to fast ridges in the Indian and Pacific oceans. This asymmetry is especially apparent for regions whose crustal ages are less than $12 \mathrm{Ma}$. Gibert and Courtillot [1990] point out two unusually high admittance values on the westem flank of the South Atlantic Ridge, at wavelengths around 700 $\mathrm{km}$, and propose that these could be due to "asthenospheric density heterogeneities". Lastly, Crane et al. [1991] have examined various models liable to produce asymmetric spreading along the Knipovitch Ridge, west of Spitsbergen.

This paper presents an joint interpretation of topography and altimetry data along profiles crossing the Mid-Atlantic Ridge. A schematic model of upper mantle convection which accounts for such an asymmetry is proposed. The interactions between convection and the MAR itself are discussed.

\section{The method}

Geoid height data along GEOSAT's ERM (Exact Repeat Mission) tracks are plotted against sea-floor topography

Copyright 1992 by the American Geophysical Union.

Paper number 92GL00918

$0094-8534 / 92 / 92$ GL-00918 $\$ 03.00$ values interpolated from the gridded DBDB5 data set. These plots are termed below "G(T) curves". For the same T, similar isostatic responses under the two ridge flanks will produce the same G, whatever the physical processes causing such responses. G/T ratios are the slopes of the $G(T)$ curves and provide a direct representation of the variations if the isostatic response mechanism. Separate plots of $T$ and $G$ as functions of the distance to the ridge axis, or as functions of the crustal age, might be harder to interpret: for example $T$ (distance) and $G$ (distance) plots are less demonstrative if the dominant effect in the isostatic response were not the distance from the ridge, but the distance to the center of the nearest topographic anomaly (either Iceland or the Azores).

$G(T)$ curves and G/T ratios are compared to those computed from a thermal subsidence law, such as that of Haxby and Turcotte [1978], by setting the initial $\mathrm{T}_{0}$ depth to the zero-age depth observed under each satellite track. Besides, the G/T ratios allow an estimation of the average depth of large-scale density anomalies if an expression of the Pratt admittance such as the one derived by Haxby and Turcotte [1978] is used. Such a compensation mechanism is deemed to be effective for a young enough oceanic lithosphere, where the crust and mantle temperature vs. depth distributions are heterogeneous in the horizontal direction. Revenaugh and Parsons [1987] and O'Connell et al. [1991] pointed out the importance of the upper mantle viscosity distribution in the compensation process. However, this process will not be considered below, as possible differences between the viscosity distributions under the two flanks of the MAR are presently unresolvable.

Two domains along the Mid-Atlantic Ridge, South of Iceland and South of the Azores have been selected. The main reasons for this choice are: 1) the density of bathymetric data, giving reliable T values interpolated from the DBDB5 gridded set; 2) well constrained crustal ages and detailed kinematic patterns; 3 ) some geochemical results -even if restricted to the axial province of the MAR-; 4) due to the low spreading rate, a wide interval of crustal ages is scanned by the satellite track segments along which $\mathrm{G} / \mathrm{T}$ ratios are computed.

Satellite altimetry data from the twelve first orbital cycles of GEOSAT (Nov. 86 - May 87) are used. Geoid height values from repetitive passes along the same ground track are interpolated at $10 \mathrm{~km}$-spaced points and stacked. No correction for ocean tides was applied, considering the very short fligth time along each orbit segment with respect to the tide period. Depth are then interpolated from the DBDB5 gridded data set at the locations of the stack points. It should be mentioned that no correction to the depth values for sediment loading has been applied, as the average sediment cover over the ridge axial province is thin. Caution was exercised as regards the possibility of averaging over different domains - especially for the Reykjanes Ridge profiles, to avoid including the Greenland Margin and the western slope of the Rockall Plateau-. The G/T values of Tables 1 and 2 have thus been computed only after visual selection of the flat parts of the $G(T)$ curves. These parts span crustal ages from magnetic chron 13 (ca. $37 \mathrm{Ma}$ ) to chron 5 (ca. $12 \mathrm{Ma}$ ).

\section{The results}

\section{The Reykjanes Ridge}

Data along five ascending tracks crossing the Reykjanes Ridge over oceanic areas younger than magnetic anomaly 13 (about $300 \mathrm{~km}$ from the ridge's axis on each flank) are inter- 
TABLE 1. Geoid over topography ratios and Pratt compensation depths over the Reykjanes Ridge

\begin{tabular}{cccc}
\hline Profile \# & Western flank & Eastern flank & model \\
\hline 5 & $3.9 \mathrm{~m} / \mathrm{km}$ & $3.1 \mathrm{~m} / \mathrm{km}$ & $2.3 \mathrm{~m} / \mathrm{km} *$ \\
& $(79 \mathrm{~km})^{+}$ & $(63 \mathrm{~km})^{+}$ & \\
4 & $4.6 \mathrm{~m} / \mathrm{km}$ & $3.3 \mathrm{~m} / \mathrm{km}$ & $2.3 \mathrm{~m} / \mathrm{km} *$ \\
& $(93 \mathrm{~km})^{+}$ & $(66 \mathrm{~km})^{+}$ & \\
3 & $4.3 \mathrm{~m} / \mathrm{km}$ & $2.5 \mathrm{~m} / \mathrm{km}$ & $2.3 \mathrm{~m} / \mathrm{km}^{*}$ \\
& $(87 \mathrm{~km})^{+}$ & $(50 \mathrm{~km})^{+}$ & \\
2 & $4.1 \mathrm{~m} / \mathrm{km}$ & $2.2 \mathrm{~m} / \mathrm{km}$ & $2.3 \mathrm{~m} / \mathrm{km}^{*}$ \\
& $(83 \mathrm{~km})^{+}$ & $(46 \mathrm{~km})^{+}$ & \\
& $2.6 \mathrm{~m} / \mathrm{km}$ & $1.5 \mathrm{~m} / \mathrm{km}$ & $2.3 \mathrm{~m} / \mathrm{km}^{*}$ \\
1 & $(53 \mathrm{~km})^{+}$ & $(31 \mathrm{~km})^{+}$ &
\end{tabular}

* Mean $\mathrm{G} / \mathrm{T}$ ratio between magnetic isochrons 6 and 13

+ Pratt compensation depth (Haxby and Turcotte, 1978)

TABLE 2. Geoid over topography ratios and Pratt compensation depths over Mid-Atlantic Ridge South of the Azores

\begin{tabular}{cccc}
\hline Profile \# & Western flank & Eastem flank & model \\
\hline 16 & $1.6 \mathrm{~m} / \mathrm{km}$ & $7.1 \mathrm{~m} / \mathrm{km}$ & $2.5 \mathrm{~m} / \mathrm{km} *$ \\
& $(32 \mathrm{~km})^{+}$ & $(144 \mathrm{~km})^{+}$ & \\
15 & $2.3 \mathrm{~m} / \mathrm{km}$ & $6.8 \mathrm{~m} / \mathrm{km}$ & $2.5 \mathrm{~m} / \mathrm{km} *$ \\
& $(47 \mathrm{~km})^{+}$ & $(138 \mathrm{~km})^{+}$ & \\
14 & $2.3 \mathrm{~m} / \mathrm{km}$ & $6.2 \mathrm{~m} / \mathrm{km}$ & $2.5 \mathrm{~m} / \mathrm{km} *$ \\
& $(47 \mathrm{~km})^{+}$ & $(126 \mathrm{~km})^{+}$ & \\
13 & $2.0 \mathrm{~m} / \mathrm{km}$ & $5.8 \mathrm{~m} / \mathrm{km}$ & $2.5 \mathrm{~m} / \mathrm{km}^{*}$ \\
& $(40 \mathrm{~km})^{+}$ & $(117 \mathrm{~km})^{+}$ & \\
12 & $0.9 \mathrm{~m} / \mathrm{km}$ & $5.5 \mathrm{~m} / \mathrm{km}$ & $2.5 \mathrm{~m} / \mathrm{km}^{*}$ \\
& $(18 \mathrm{~km})^{+}$ & $(111 \mathrm{~km})^{+}$ & \\
11 & $0.8 \mathrm{~m} / \mathrm{km}$ & $4.3 \mathrm{~m} / \mathrm{km}$ & $2.5 \mathrm{~m} / \mathrm{km}^{*}$ \\
\multicolumn{5}{c}{$(16 \mathrm{~km})^{+}$} & $(87 \mathrm{~km})^{+}$ \\
\hline
\end{tabular}

preted, excluding values over the Greenland margin and over the Rockall Plateau (Figure 1). Figure 2 depicts $G(T)$ curves $\mathrm{G} / \mathrm{T}$ ratios listed Table 1 . Thermal sea-floor and geoid subsidence model values are computed for the ages of several magnetic chrons from Haxby and Turcotte [1978].

The striking asymmetrical nature of the Reykjanes Ridge stands out on the $G(T)$ plots (Figure 2). The asymmetry is less pronounced along track 5 , running over shallow waters close to Iceland. Along the other tracks a steeper G/T slope is observed under the Ridge's western flank for all age periods. The G(T) curve for this flank clearly departs from that corresponding to a thermal subsidence model. G/T ratios for each track are listed Table 1. In terms of Pratt compensation levels [Haxby and Turcotte, 1978], the G/T ratios correspond to depths ranging northwards from 53 to $79 \mathrm{~km}$ on the western flank and from 31 to $63 \mathrm{~km}$ on the eastern one.

\section{The MAR South of the Azores}

The possibility that the mantle asymmetry observed under the Reykjanes Ridge be unique to this area prompted us to conduct a similar study South of the Azores, where reliable bathymetric data and some geochemical results are also available.

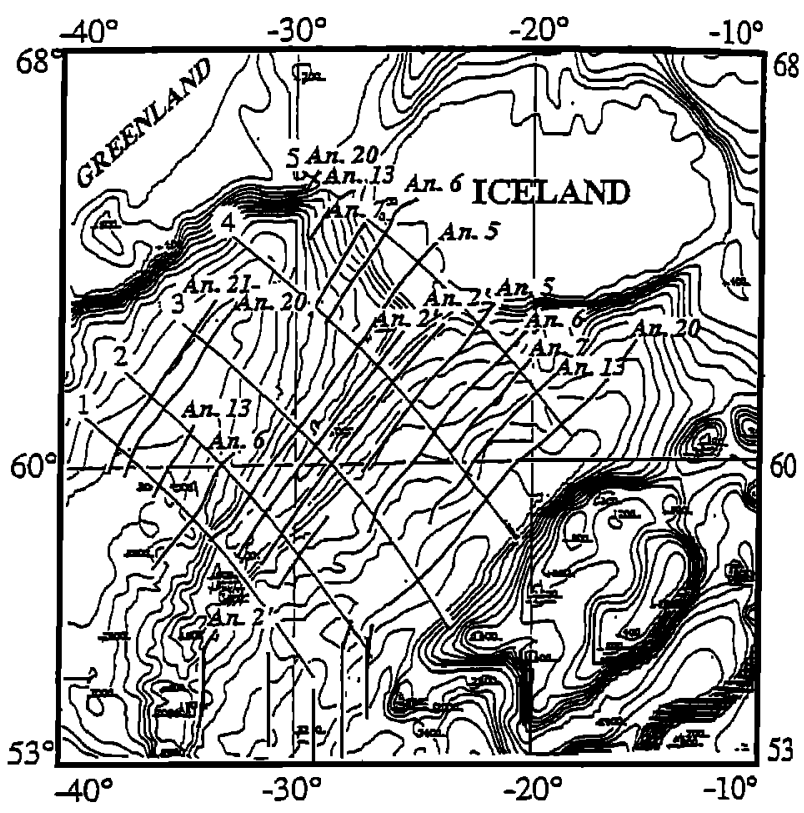

Fig. 1. Selected GEOSAT ascending tracks over the Reykjanes Ridge (track segments have been re-numbered from South to North and do not correspond to any NASANODC figures). $500 \mathrm{~m}$-spaced isobaths are interpolated from the DBDB5 gridded data set.

Figure 3 shows the location of the six satellite tracks along which $G(T)$ curves ( Figure 2 ) and $G / T$ ratios (Table 2 ) where computed. Interpretation of these results suggests similar conclusions to those proposed for the Reykjanes Ridge: a northward increase of the $G / T$ ratios toward the Azores and a very strong asymmetry between the two flanks of the Ridge. The asymmetry is even more pronounced than under the Reykjanes Ridge: the average $G / T$ value on the northwestem flank being over four-fold lower than the one computed for the southeastern flank. The Pratt compensation depths [Haxby and Turcotte, 1978] range between under $20 \mathrm{~km}$ below the north-western flank to over $140 \mathrm{~km}$ below the southeastern one. It is interesting to notice that the overall average $\mathrm{G} / \mathrm{T}$ value (about $3.6 \mathrm{~m} / \mathrm{km}$ ) is close to the average slope of a bimodal set of $\mathrm{G}(\mathrm{T})$ values found by Cazenave et al. [1988] over a box centered on the Azores.

\section{Discussion and model}

The $\mathrm{G} / \mathrm{T}$ ratios are the limit values of the admittances for infinite wavelengths. Therefore, though they were approached by computation over finite-length profiles, they included little effects from shallow processes such as crustal thickness variations or other local isostatic response mechanisms. In any case, G/T ratios have been computed for the two ridge flanks over areas of similar crustal age (between magnetic chrons 13 and 5), irrespective of their distance to the ridge axis. This allows to discard crustal effects which would depend on the variation of the crustal thickness with age. Moreover, if crustal thickness variations along the ridge participate in the $\mathrm{G} / \mathrm{T}$ asymmetry, because of the obliquity of the orbits with respect to the flow-lines, this participation is probably quite small: a fifty percent increase in the crustal thickness -from 6 to $9 \mathrm{~km}$ - would induce a $400-\mathrm{m}$ depth anomaly if simple isostatic mass balance is considered [Sheehan and Solomon, 1991]. While this would indeed bring some changes in the asymmetry ratio, this would not be sufficient to account for the asymmetry itself. 

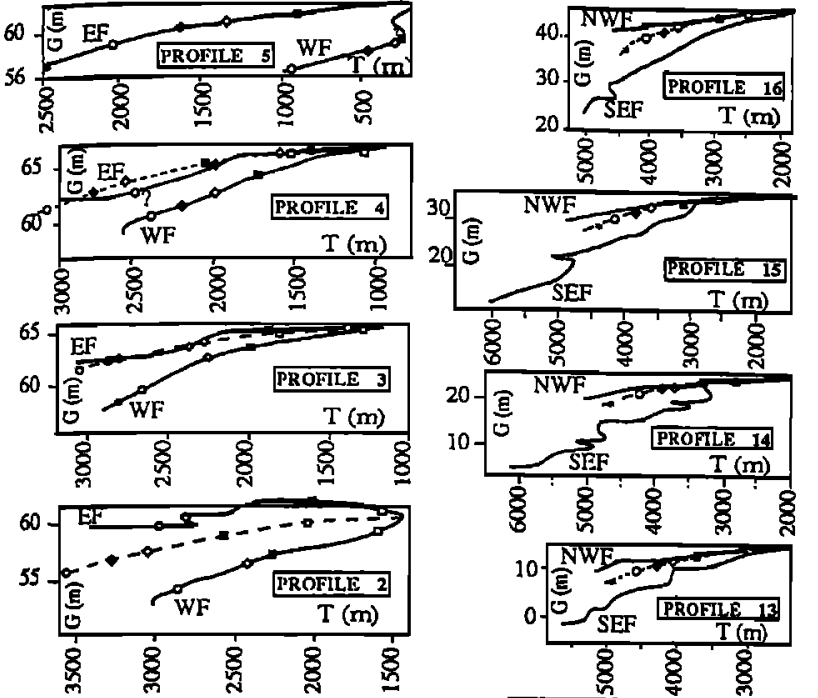

60
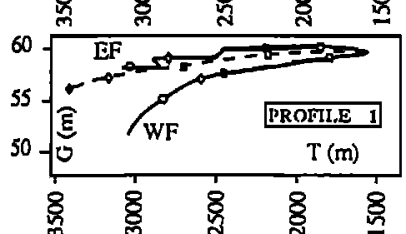

a Anomaly 2'* Anomaly $\gamma$

- Anomaly 5 o Anomaly 13 . Anomaly 21

Anomaly 6 . Anomaly 20

EF : Eastern Flank WF : Western Flank

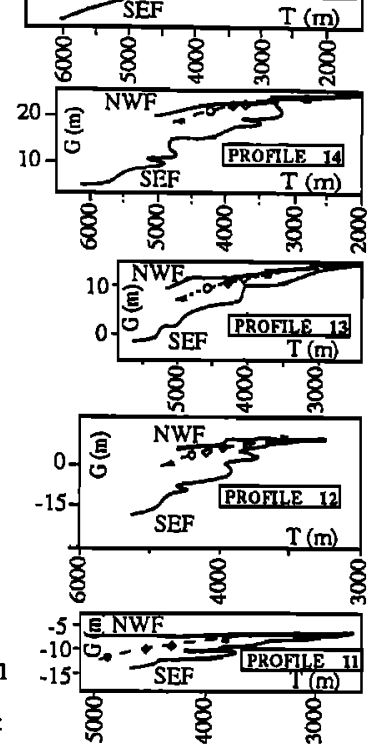

Fig. 2 . G(T) plots over the Reykjanes Ridge and over the MAR, south of the Azores. The dotted line is the depth/geoid subsidence curve computed from the cooling model of Haxby and Turcotte [1978]. Symbols indicate the values of T and G at the crossing points between satellite tracks and magnetic chrons. Same symbols are used along the model curve.

We therefore consider that the asymmetry of the G/T ratios mostly reflect upper mantle heterogeneities under the MAR.

The possibility that the observed asymmetry of the mantle structure be the result of an artifact due to the particular orientations of the satellite's tracks with respect to the general trend of the ridge can be ruled out: asymmetry of opposite polarity is observed close to Iceland and near the Azores, while the orientations of the tracks with respect to the ridge are fairly similar in both areas.

The misfit between the observed $\mathrm{G} / \mathrm{T}$ ratios and those derived from a pure cooling model [Haxby and Turcotte, 1978] cannot be overcome by a reasonable change in the parameters of the model G/T ratio. Other models with symmetrical mantle temperature would produce comparable misfits. Moreover, as remarked by Hayes [1988] concerning the depth/age ${ }^{1 / 2}$ asymmetry South of Australia, such an asymmetry in the parameters $(\alpha, \mathrm{T}$ and $\mathrm{k})$ is unlikely, as both flanks were created at the same location, with the same initial thermal and petrological conditions. It therefore appears that "symetrical cooling models" cannot account for the observed G/T ratios.

It is therefore proposed that the observed asymmetry in the $\mathrm{G} / \mathrm{T}$ ratios is due to an asymmetrical distribution of the temperatures at depth. This asymmetry in the upper mantle temperature distribution does not need to be very large: Buck and $\mathrm{Su}$ [1989] proposed that small lateral temperature variations can set small-scale convection in an asthenosphere with temperature-dependent viscosity, leading in turn to large changes in the subsidence rate. Such a model alleviates the need of "unreasonably asymmetric" temperature distribution at depth.

$\mathrm{G} / \mathrm{T}$ ratios listed Tables 1 and 2 show a systematic increase

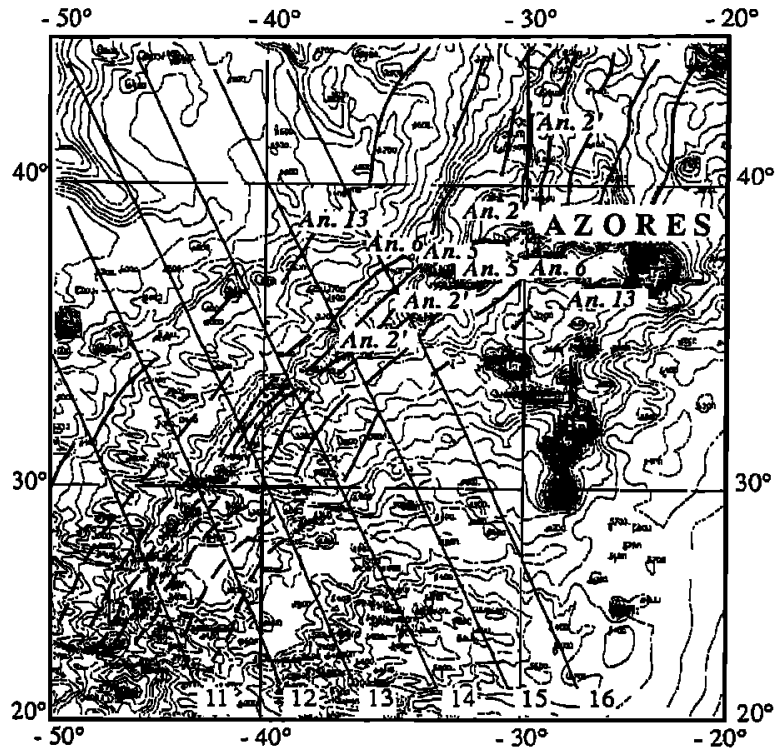

Fig. 3. Same as figure 1 South of the Azores.

northward toward Iceland, paraleling the increase in $\mathrm{La} / \mathrm{Sm}$, ${ }^{87} \mathrm{Sr} /{ }^{86} \mathrm{Sr}$ and ${ }^{3} \mathrm{He} /{ }^{4} \mathrm{He}$ ratios [Poreda et al., 1986], and towards the Azores. It has been noted [Aslanian and Goslin, 1990] that these systematic variations of $G / T$ ratios on both flank are correlated to the distance to the closest topographic anomaly. It seems improbable however that their asymmetry solely reflect a chaneling under the ridge axis of hot mantle material from an off-centered mantle plume of limited radius: as mentioned above, $\mathrm{G} / \mathrm{T}$ ratios have been computed over $300-\mathrm{km}$ wide areas, centered about $200 \mathrm{~km}$ away from the ridge axis.

Our results bear out that the mantle structure is asymmetric, at least under the post-Eocene oceanic domain created at the Mid-Atlantic Ridge. Such a feature is also clearly visible on the $V_{S V}$ wave velocity distribution at a depth of $100 \mathrm{~km}$ [Montagner and Tanimoto, 1991]: lower velocities, which could be indicative of a hotter mantle, are observed under the northwestern flank of the Reykjanes Ridge and under the southeastern flank of the MAR South of the Azores, where we have evidenced higher $\mathrm{G} / \mathrm{T}$ ratios. The mantle asymmetry could be due to the relative and absolute motions of plates (and, hence of the MAR, tied to convection cells in the lowviscosity zone) over distributed large-scale, deep-mantle convection cells, which reacts little -or not at all- to this motion. Such an hypothesis accounts for the change of polarity of the asymmetry between various portions of the MAR (Figure 4). Houseman [1983] considers that the timescale for heat transfer between convection cells is very large compared to the timescale of ridge motion: as the ridge moves, the ascending limbs of the upper convection cells would not be reset over the ascending limbs of deep mantle convection ( Figure 4).

A second type of hypotheses supposes that the asymmetrical processes which could be dominant at various depths during the early phases of rifting, e.g. in the case of asymmetric pure shear, persist throughout the lifespan of a mature ocean. The major problem induced by such an hypothesis, leading us to reject it, is the need for a complicated mechanism to ensure the "asymmetry memory" of the Mid-Atlantic Ridge since these early phases.

In summary, the preliminary interpretation of geoid and topography data at a regional scale over two regions of the MAR brings evidence for a strong asymmetry of the deep processes active under this spreading center. This type of hypothesis matches recently published seismic tomography results. 


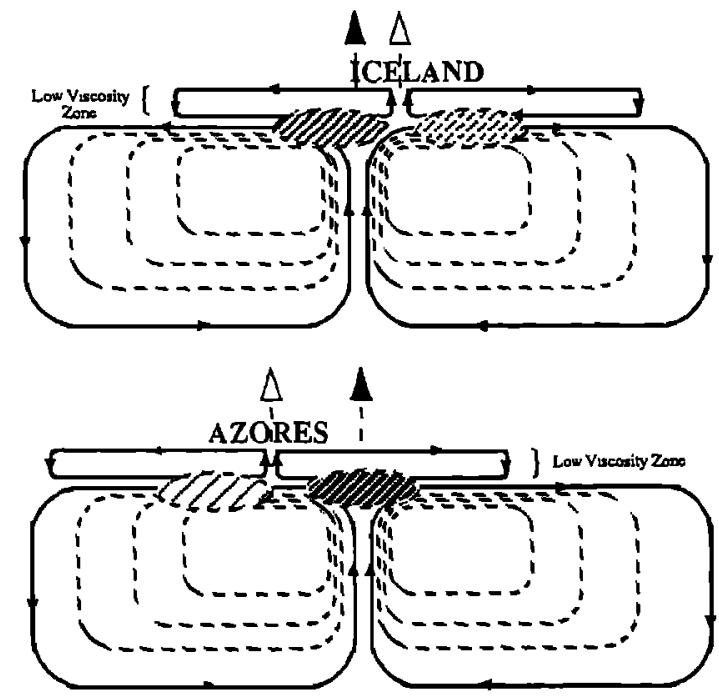

Fig.4 . Simplified sketch of the North Atlantic Ridge, mobile with respect to convection-induced thermal heterogeneities. Shaded ovals symbolize temperature anomalies, darker shades indicate hotter zones. Arrows indicate the location of the ascending limb of the deep mantle convection. Open arrows show the location of the Mid-Atlantic Ridge.The respective position of the arrows accounts for the polarity of the asymmetry. The greater distance between arrows on the lower sketch corresponds to a more pronounced asymmetry South of the Azores.

Heat flow and geochemical studies of slow spreading centers, when conducted over areas of sufficiently wide range of ages (a few $10 \mathrm{My}$ ?), might certainly help and argument this hypothesis of a ridge moving over an heterogeneous mantle.

Acknowledgments. Discussions with $\mathrm{K}$. Louden while he was interpreting heat-flow data in the North Atlantic certainly played a key role in initiating this work. He was also helpful in the tedious early steps of GEOSAT data processing. $Y$. Lagabrielle kept a geologist's eye. The comments of two anonymous reviewers helped us to clarify some important points of the discussion. Contribution 456 of the CNRS-INSU-DBT Program (Thème :"Dynamique Globale").

\section{References}

Aslanian, D. et Goslin, J., Extension des anomalies thermiques profondes de l'Islande et des Açores d'après l'interprétation des données altimétriques , paper presented at the Soc. Géol. Fr. Meeting "Géodynamique des océans et de leurs marges". Sophia Ántipolis, 1990.

Buck, W.R. and Su, W., Focused mantle upwelling below mid-ocean ridges due to feedback between viscosity and melting, Geophys. Res. Lett., 16, 641-644, 1989.

Cazenave, A., Dominh, K., Rabinowitz, M. and Ceuleneer, G., Geoid and depth anomalies over ocean swells and troughs: evidence of an increasing trend of the geoid to depth ratio with age of plate, J. Geophys. Res., 93, 8064 $8077,1988$.

Cochran, J.R., Variations in subsidence rates along intermediate and fast spreading mid-ocean ridges, Geophys. J. R. astr. Soc., 87, 421-454, 1986.

Crane, K., Sundvor, E., Buck, R. and Martinez, F., Rifting in the Northern Norwegian-Greenland Sea: thermal tests of asymmetric spreading, J. Geophys. Res., 96, 14,529. $14,551,1991$.
Dupré, B. and Allègre, C.J., $\mathrm{Pb} \mathrm{Sr} \mathrm{Nd}$ isotopic correlation and the geochemistry of the North Atlantic mantle, Nature. 286, 17-21, 1980.

Forsyth, D.W., Symmetric topography - asymmetric gravity anomalies across segments of the Mid-Atlantic Ridge, EOS, 71, 624, 1990 .

Gibert, D. and Courtillot, V., Thermal isostasy in the South Atlantic: a new approach, Geophys. Res. Lett., 17, 251 $254,1990$.

Haxby, W.F. and Turcotte, D.L., On isostatic geoid anomalies, J. Geophys. Res., 83, 5473-5478, 1978.

Hayes, D.E., Age-depth relationships and depth anomalies in the Southeast indian ocean and South Atlantic Ocean, J. Geophys. Res., 93, 2937-2954, 1988.

Honda, S. and Tanimoto, T., Regional 3-D heterogeneities by waveform inversion. Application to the Atlantic area Geophys. J. R. Astron. Soc., 91, 737-753, 1987.

Houseman, G., The deep structure of oceanic ridges in a convective mantle, Earth Planet. Sci. Lett. 64, 283-294, 1983.

Montagner, J.-P. and Tanimoto, T., Global upper mantle tomography of seismic velocities and anisotropies, J. Geophys. Res., 98, 20337-20351, 1991.

Nicolas, A., Structures of ophiolites and dynamics of oceanic lithosphere, Kluwer Acad. Press, Dordrecht, 367 pp., 1989.

O'Connell, R.J., Gable, C.W. and Hager, B.H., Toroidalpoloidal partitioning of lithospheric plate motions, in Glacial Isostasy, sea level and mantle rheology $R$. Sabadini (Ed.), NATA ASI Series, Kluwer Acad. Pub., 1991.

Patriat, Ph., Reconstitution de l'évolution du système de dorsales de l'océan Indien par les méthodes de la cinématique des plaques, Thèse de Doctorat d'Etat, 308 pp., Université Paris VI, 1987.

Phipps Morgan, J., Parmentier, E.M. and Lin, J., Mechanisms for the mechanisms of mid-oceanic ridge axial topography: implications for the thermal and mechanical structure of accreting plate boundaries, I. Geophys. Res, 22, 12823-12836, 1987.

Poreda, R., Schilling, J-G. and Craig, H., Helium and hydrogen isotopes of ocean-ridge basalts North and South of Iceland, Earth Planet. Sci. Lett., 78, 1-17, 1986.

Revenaugh, J. and Parsons, B.E., Dynamic topography and gravity anomalies for the fluid layers whose viscosity varies exponentially with depth, Geophys. J.R. Astr. Soc., 91, 557-568, 1987.

Schilling, J-G., Iceland mantle plume: geochemical study of the Reykjanes Ridge, Nature, 242, 565-571, 1973.

Schilling, J-G., Zajac, M., Evans, R., Johnston, T., White, W., Devine, J. D. and Kingsley, Petrologic and geochemical variations along the Mid-Atlantic Ridge from $29^{\circ} \mathrm{N}$ to $73^{\circ} \mathrm{N}$, Am. J. Sci., 283, 510-586, 1983.

Sheehan, A. F. and Solomon, S. C., Joint inversion of shear wave travel time residuals and geoid and depth anomalies for long-wavelength variations in upper mantle temperature and composition along the Mid-Atlantic Ridge, J. Geophys. Res., 96, 19981-20009.

Toomey, D.R., Solomon, S.C. and Purdy, G.M., Microearthquakes beneath median valley of Mid-Atlantic Ridge near $23^{\circ} \mathrm{N}$ : tomography and tectonics, J. Geophys. Res., 93, 9093-9112, 1988 .

J. Goslin and D. Aslanian, URA $1278 \mathrm{du}$ CNRS "Domaines Océaniques", Université de Bretagne Occidentale, 29287 Brest cedex, France.

(Received: October 10, 1991;

Revised: March 5, 1992;

Accepted, April 20,1992) 